Universal Decimal Classification (UDC) number 613.64: 616.717 - 057

\title{
CHARACTERISTICS OF GENE POLYMORPHISM IN WOMEN WITH A THREAT OF MISCARRIAGE AND AIRBORNE EXPOSURE TO PHENOLS
}

\author{
O.V. Dolgikh1,2,3, A.V. Krivtsov¹, O.A. Bubnova3 ${ }^{3}$ V.B. Alexeyev1,3 \\ ${ }^{1}$ FBSI «Federal Scientific Center for Medical and Preventive Health Risk Management Technologies», \\ Russian Federation, Perm, 82 Monastyrskaya St., 614045, \\ 2 Federal State Budget Educational Institution of Higher Professional Education «Perm National Research \\ Polytechnic University», Russian Federation, Perm, 29 Komsomolskiy Ave, 614990, \\ ${ }^{3}$ Federal State Budget Educational Institution of Higher Professional Education «Perm State National \\ Research University», Russian Federation, Perm, 15 Bukireva St., 614990
}

\begin{abstract}
The conducted assessment of the genetic diagnostic results has shown characteristics of genetic polymorphism of detoxification and reproduction genes CYP1A1, CPOX, SULT1A1 and ESR1. The determined genetic characteristics in the study group of women were mainly represented by mutations of genes which are responsible for enzyme-binding detoxification activity and which mainly have heterozygous differences. The data presented show negative genetic associations between exposure to phenol and threatened miscarriages.
\end{abstract}

Key words: phenols, threatened miscarriage, detoxification genes, estrogen receptor 1 gene.

Reproductive health of women of childbearing age is one of the most socially relevant indicators characterizing the health of the society, and is largely dependent on adverse effects of environmental factors $[3,4,5]$. Relevant is identification of genetic markers that can be used as criteria for assessment of reproductive function and for characterization of pregnancy losses in women of childbearing age under changed conditions of the environment $[3,4]$.

The use of modern diagnostic immunological and molecular genetic technologies, in particular, flow cytometry and polymerase chain reaction (PCR), allows an objective and accurate assessment of the immune response and polymorphism of genes responsible for the immune response in women with miscarriages under conditions of high technological chemical load. Analysis and subsequent use of modern diagnostic criteria further expands the existing evidences on identification of causal relationships for pathological and premorbid conditions with the exposure to chemical environmental factors [2-4, 6].

The aim of the study was to assess the characteristics of single-nucleotide polymorphisms in women with threatened miscarriage under conditions of chronic aerogenic

\footnotetext{
(c) Dolgikh O.V., Krivtsov A.V., Bubnova O.A., Alexeyev V.B., 2013

Dolgikh Oleg Vladimirovich - Professor, DSc in Medicine, Head of the Department of Immunobiological Diagnostics (e-mail: oleg@fcrisk.ru, tel.: 8 (342) 236-39-30).

Krivtsov Alexandr Vladimirovich - PhD in Medicine, Head ofthe Immunogenetics Laboratory (e-mail: oleg@fcrisk.ru, tel.: 8 (342) 236-39-30).

Bubnova Olga Alexeyevna - PhD in Medicine, Junior Researcher, the Immunogenetics Laboratory (e-mail: oleg@fcrisk.ru, tel.: 8 (342) 236-39-30).

Alexeyev Vadim Borisovich - DSc in Medicine, Deputy Director for Organizational and Methodical Work (e-mail: vadim@fcrisk.ru, tel.:+7 (342) 237-25-34).
} 
exposure to phenols.

Materials and methods. Immunological diagnostic testing of women with threatened miscarriage, living in Perm, was carried out: 22 of them (monitoring group) were exposed to chemical load, 24 - were outside of the exposure zone (comparison group).

Sampling for PCR was carried out using mucosal smears from the oropharynx. Then DNA was isolated using sorbent method which is based on the cell destruction with subsequent sorption of nucleic acids on a sorbent.

To study polymorphic variants of the studied genes, PCR technique was used, based on the amplification reaction and real-time detection of the reaction products using fluorescent labels marking primers for amplification reaction. For simultaneous detection of multiple reaction products, different fluorescent labels and probes (multiplex PCR) are used. As the primers, a region of DNA of CYP1A1, CPOX, SULT1A1, ESR1 genes was used. To determine the human genotype, allelic discrimination method was used, when the differences between heterozygotes and homozygous wild-type and homozygous minor alleles were determined by the differences in the reactions of amplification of appropriate primers.

The marker of exposure was the blood level of chemicals with reprotoxic potential (phenols). Determination of organic compounds $(\mathrm{mg} / \mathrm{l})$ was carried out in accordance with Methodological Guidelines 4.1.2102-4.1.2116-06 using gas chromatography [7].

Statistical analysis of the study results was carried out using modern methods of mathematical statistics (parametric t-test based on the normal distribution of variables in the compared groups; Spearman's rank correlation coefficient). Differences between the groups were considered statistically significant at $\mathrm{p}<0.05$ [1].

Results and discussion. Testing of ambient air quality was focused on determination of the contents of 15 compounds (phenol, cresols, formaldehyde, benzo(a)pyrene, fine powder dust fraction $\mathrm{PM}_{2,5}$ and $\mathrm{PM}_{10}$, chromium, nickel, manganese and its compounds, lead, vanadium pentoxide, copper oxide, silica oxide). However, during analysis the priority was given to phenol and cresol as the substances that are specific to the particular industrial site, are constantly present in the ambient air and are referred to reprotoxicants.

The results of field studies of the ambient air quality determined excessive single and average-daily concentrations in the atmosphere compared to the values set by hygienic standards for phenol - up to $2.3 \times$ Average daily maximum permissible concentration; for $\mathrm{p}$-, $\mathrm{m}$ - cresol - up to $2.0 \times$ Average daily maximum permissible concentration, and up to $7.4 \times$ Acute Exposure Threshold Limit; for o-cresol-up $2.0 \times$ Acute Exposure Threshold Limit.

As a result of chemical-analytical analysis of the content of contaminants in the blood of 
women in the monitoring group, a significant excess of the regional background level of tricresol was found, and the content of cresols differed from the background concentration corresponding to the zero value (Table 1).

There was a significant 2.6- and 3.2-fold increase in the content of o-cresol and p-, mcresol, respectively in the blood of women living under conditions of exogenous exposure to phenols, versus the comparison group. The results of genetic DNA analysis and the identified abnormalities are shown in Table 2. Polymorphism of detoxification and reproduction genes CYP1A1, CPOX, SULT1A1, and ESR1 (cytochrome and coproporphirinogene-oxidase genes) characterises the main differences between the two groups of women. Frequency of the pathological CYP1A1 allele in the main group was significantly $(p<0.05) 2.5$-fold higher than in the comparison group.

Table 1

Tricresol content in the blood of women with threatened miscarriage $(\mathrm{n}=46), \mu \mathrm{g} / \mathrm{cm}^{3}$

\begin{tabular}{|c|c|c|c|c|}
\hline Indicator & $\begin{array}{c}\text { Main group } \\
(\mathrm{n}=22)\end{array}$ & $\begin{array}{c}\text { Comparison group } \\
(\mathrm{n}=24)\end{array}$ & $\begin{array}{c}\text { Background } \\
\text { concentrations }\end{array}$ & $\begin{array}{c}\text { Multiplicity of } \\
\text { differences with the } \\
\text { comparison group }\end{array}$ \\
\hline $\mathrm{p}$-,m-cresol & $0,0097 \pm 0,0030^{*}$ & $0,0038 \pm 0,004$ & 0 & 2,6 \\
\hline O-cresol & $0,0165 \pm 0,005^{*}$ & $0,0052 \pm 0,0039$ & 0 & 3,2 \\
\hline
\end{tabular}

Note : * - significant differences with the comparison group and the background $(p<0,05)$.

Table 2

Distribution of gene frequencies in women with threatened miscarriage

\begin{tabular}{|c|c|c|c|}
\hline $\begin{array}{l}\text { Gene (single nucleotide } \\
\text { polymorphism) }\end{array}$ & $\begin{array}{l}\text { Genotype/ } \\
\text { allele }\end{array}$ & Main group, \% & Comparison group, $\%$ \\
\hline \multirow{5}{*}{$\begin{array}{l}\text { Cytochrome P-450 } \\
\text { (CYP1A1) }\end{array}$} & GG & 68,2 & 82,4 \\
\hline & $\mathrm{AG}$ & 4,5 & 5,9 \\
\hline & AA & $27,3^{*}$ & 11,8 \\
\hline & $G$ & 70 & 89 \\
\hline & $\mathrm{A}$ & $30 *$ & $11 / 10$ \\
\hline \multirow{5}{*}{$\begin{array}{l}\text { Coproporphirinogene- } \\
\text { oxidase (CPOX) }\end{array}$} & GG & 54,5 & 78,3 \\
\hline & $\mathrm{AG}$ & $40,9 *$ & 21,7 \\
\hline & AA & 4,5 & 0 \\
\hline & $\mathrm{G}$ & 75 & 89 \\
\hline & $\mathrm{A}$ & $25^{*}$ & $11 / 15$ \\
\hline \multirow{5}{*}{$\begin{array}{l}\text { Sulfotransferase } \\
\text { (SULT1A1) }\end{array}$} & GG & 27,3 & 34,8 \\
\hline & $\mathrm{AG}$ & $54,5^{*}$ & 39,1 \\
\hline & $\mathrm{AA}$ & 18,2 & 26,1 \\
\hline & $\mathrm{G}$ & 54,5 & 54 \\
\hline & $\mathrm{A}$ & 45,5 & $46 / 31$ \\
\hline \multirow{5}{*}{$\begin{array}{l}\text { Estrogen receptor } \\
\text { (ESR1) }\end{array}$} & GG & 73,7 & 75 \\
\hline & $\mathrm{AG}$ & 26,3 & 25 \\
\hline & AA & 0 & 0 \\
\hline & $\mathrm{G}$ & 87 & 87,5 \\
\hline & $\mathrm{A}$ & 13 & $12,5 / 10$ \\
\hline
\end{tabular}

Note : ${ }^{*}$ - significant differences with the comparison group $(p<0,05)$. 
A negative distribution of frequencies of detoxification genes (CYP1A1, CPOX, SULT1A1) is found, characterized by a significantly increased prevalence of heterozygous variants of CPOX and SULT1A1 gene versus the comparison group $(p<0,05)-2.0$ and 1.5-fold, respectively (see Table 1). The associations found are compounded by the fact that among the women living in the zone of exposure to phenols an increased incidence of minor homozygotes of CYP1A1 gene (2.5-fold) is observed, as well as of heterozygotes of CPOX, SULT1A1 genes, which indicates the presence of negative genetic variability with predisposition to cancer development. The SULT1A1 gene (thermostable phenol-sulfotransferase) catalysing not only conjugation with sulfates of phenol, nitrophenol and other simple derivatives of phenol, but also estrogen metabolism, demonstrates significantly higher polymorphism, exceeding the quoted one.

According to the results of genetic testing, it can be concluded that in the group of women living outside of the area at risk, immunological tolerance to child-bearing develops according to standard principles of development of intragenital pathology.

At the same time changes and characteristics of genetic polymorphism and the development of pathology in women living in the zone of exposure, indicate the presence of additional factors, which also lead to the miscarriage, but this miscarriage is determined by genetic disturbances of phenol detoxification enzymes. Genetic patterns in the main group of women are determined, characterized by mutations in the genes responsible for enzyme-reducing and enzyme-binding detoxification activity - cytochrome coproporphirinogene-oxidase, and sulfotransferase.

Conclusions. Thus, assessment of the gene polymorphism analysis has identified patterns of genetic polymorphism of detoxification genes CYP1A1, CPOX, SULT1A1 and estrogen receptor gene, as well as and their association with contamination of biological media with phenols. These data suggest the negative immunogenetic associations of the exposure to phenols with the threat of miscarriage. Marking sensitive genetic indicators will be the basis of the development of criteria of the comprehensive assessment of extra- and intragenital pathology under conditions of exposure to phenol and its derivatives, such as o-, $\mathrm{m}$ - and p-cresols.

\section{References}

1. Glanc S. Mediko-biologicheskaja statistika [Biomedical statistics]. Ed. N.E. Buzikashvili i soavt. Moscow: Praktika, 1998. 459 p.

2. Zajceva N.V., UstinovaO.Ju., Aminova A.I. Gigienicheskie aspekty narushenija zdorov'ja detej pri vozdejstvii himicheskih faktorov sredy obitanija [Environmental health aspects of medical disorders in children exposed to environmental chemical factors]. Perm': Knizhnyj format, 2011. 489 p. 
3. Dolgih O.V., Krivcov A.V., Harahorina R.A., Lanin D.V. Immunnye i DNKmarkery vozdejstvija tehnogennoj nagruzki [Immune and DNA markers of technogenic exposure]. Vestnik Ural'skoj medicinskoj akademicheskoj nauki, Moscow, 2012, no. 4, pp. $240-241$.

4. Kucenko S.A. Osnovy toksikologii [Basics of toxicology]. - SPb.: Voennomedicinskaja akademija

im. S.M. Kirova, 2002. 395 p.

5. Lanin D.V. Analiz koreguljacii immunnoj i nejrojendokrinnoj sistem $v$ uslovijah vozdejstvija faktorov riska [The analysis of the co-regulation between the immune and neuroendocrine systems under exposure to risk factors].Analiz riska zdorov'ju, 2013, no. 1, pp. $73-81$.

6. RahmaninJu.A., Novikov S.M., Ivanov S.I. Sovremennye nauchnye problemy sovershenstvovanija metodologii ocenki riska zdorov'ju naselenija [Current scientific issues of improving the health risk assessment methodology]. Gigiena $i$ sanitarija, 2005, no. 2, pp. 3-8.

7. Sbornik metodik po opredeleniju himicheskih soedinenij v biologicheskih sredah. MUK MZ RF

No. 763-99-4.1.779-99 [A digest of methods for the determination of chemical compounds in biological media. Methodical guidelines of the Russian Federation Ministry of Health no. 763-99-4.1.779-99]. Moscow, 1999. 